JURNAL SEKRETARIS \& ADMINISTRASI BISNIS

Jurnal homepage http /ljurnal asmtb ac id/inde $\times \mathrm{php} / \mathrm{jsab}$

\title{
PENGARUH PERSEPSI BANK SYARIAH DI INDONESIA TERHADAP CUSTOMER SWITCHING INTENTION DENGAN CUSTOMER SATISFACTION SEBAGAI MEDIATOR
}

\author{
Anisa Miftahul Jannah ${ }^{1}$, Arry Widodo ${ }^{2}$ \\ ${ }^{1,2}$ Program Studi Administrasi Bisnis, Fakultas Komunikasi dan Bisnis, Universitas Telkom \\ 12anisamifta5@gmail.com, ${ }^{2}$ arry.widodo@telkomuniversity.ac.id
}

\section{ARTICLE INFO \\ Article history: \\ Received $20^{\text {th }}$ January 2018 \\ Received in revised form $09^{\text {th }}$ February 2018 \\ Accepted $16^{\text {th }}$ February 2018}

\section{Keywords: \\ Perception, \\ customer satisfaction, \\ customer switching intention.}

\begin{abstract}
Indonesia's banking industry is still dominated by conventional banking. Sharia banking in Indonesia should use competitive marketing strategies and pay particular attention to the behavior of communities to compete in the national and global banking environment. This study aims to determine the effect of perception of sharia banks in Indonesia to customer switching intention with mediated by customer satisfaction. This research uses descriptive analysis method. Data collection techniques using questionnaires with Likert scale distributed to 100 customers of conventional banks. Hypothesis testing is done by using PLS (Partial Least Square). The results of this study indicate that the perception of sharia banks affect positively and significantly to customer satisfaction and influence directly or indirectly through customer satisfaction as a mediator of customer switching intention.
\end{abstract}

@ 2018 ASMTB PRESS

\section{Pendahuluan}

Industri perbankan Indonesia saat ini masih di dominasi oleh perbankan konvensional (www.tribunnews.com, 2016). Perbankan syariah di Indonesia harus menggunakan strategi pemasaran yang kompetitif dan memberikan perhatian khusus kepada perilaku masyarakat untuk berkompetisi dalam lingkungan perbankan nasional maupun global.

Salah satu penyebab masyarakat enggan beralih dari bank konvensional adalah adanya persepsi negatif terhadap bank syariah (www.tribunnews.com, 2016). Terdapat 3 persepsi masyarakat yang salah tentang bank syariah. Persepsi pertama yaitu perbankan syariah hanya diperuntukkan bagi orang muslim, padahal bank syariah dapat digunakan oleh siapa saja karena tidak berkaitan dengan ritual keagamaan Islam. Bank syariah terbuka bagi semua orang yang ingin memanfaatkan pembiayaan dengan berdasar prinsip islam. Persepsi kedua bank syariah dianggap memiliki produk yang terbatas jika dibandingkan dengan bank konvensional, produk bank syariah tidak berbeda jauh dengan bank konvensional pada umumnya, hanya saja prinsip kegiatan usahanya menggunakan prinsip syariah. Persepsi ketiga yaitu masyarakat menganggap bahwa menabung di bank syariah tidak memberikan keuntungan, hal ini karena dalam sistem bank syariah tidak mengenal bunga karena dinilai riba dalam ajaran islam, akan tetapi bank syariah menggunakan sistem bagi hasil dalam kegiatan usahanya mulai dari penghimpunan hingga penyaluran dana (http://www.tribunnews.com/bisnis/2016/07/01/tigapersepsi-yang-selama-ini-salah-tentang-bank-syariah). 
Minimnya informasi yang di dapat oleh masyarakat karena kurangnya sosialisasi dari bank syariah membentuk persepsi yang negatif. Masyarakat beranggapan bahwa bank konvensional telah didukung oleh teknologi informasi canggih sehingga pelayanan terhadap masyarakat lebih cepat. Selain itu masyarakat beranggapan bahwa bank konvensional memberikan kemudahan dan kantor layanan tersebar di seluruh pelosok sedangkan bank syariah jumlahnya masih sedikit, sehingga akan menyulitkan jika harus bertransaksi baik melalui bank langsung maupun melalui ATM (http://www.gomuslim.co.id/read/opini/2017/04/08/3732/bank-halal-itu-bernama-banksyariah.html).

Keberhasilan pengelolaan bank syariah di suatu Negara salah satunya dapat dilihat dari seberapa besar pangsa pasar yang diperoleh dan tingkat kepercayaan terhadap suatu bank berdasarkan kualitas pelayanan. Tabel 1.1 berikut merupakan tabel pangsa pasar perbankan syariah di dunia.

Tabel 1.1

Pangsa Pasar Perbankan Syariah Dunia Juni 2017

\begin{tabular}{|l|l|}
\hline Negara & $\begin{array}{l}\text { Pangsa } \\
\text { Pasar }\end{array}$ \\
\hline Saudi Arabia & $51,2 \%$ \\
\hline Kuwait & $45,2 \%$ \\
\hline Bahrain & $29,3 \%$ \\
\hline Qatar & $25,8 \%$ \\
\hline Malaysia & $21,3 \%$ \\
\hline Uni Emirate Arab & $21,3 \%$ \\
\hline Turki & $5,5 \%$ \\
\hline Indonesia & $5,3 \%$ \\
\hline
\end{tabular}

Sumber:https://ekbis.sindonews.com/read/1211638/178/mayoritas-penduduk-muslim-ri-masih-terbelakang-dalamindustri-syariah-1496842044 diakses pada tanggal 23 September 2017.

Tabel 1.1 menyatakan bahwa pada bulan Juni tahun 2017 negara dengan pangsa pasar perbankan syariah tertinggi adalah Saudi Arabia dengan jumlah pangsa pasar sebesar 51,2\%, dan negara dengan pangsa pasar perbankan syariah terendah adalah Indonesia sebesar 5,33\%. Pangsa pasar perbankan syariah Indonesia masih jauh di bawah Malaysia dengan jumlah pangsa pasar sebesar 21,3\%, yang artinya industri perbankan syariah di Indonesia saat ini masih belum dapat bersaing dengan industri perbankan di negara-negara mayoritas islam lainnya dan persepsi masyarakat terhadap bank syariah masih sangat rendah sehingga masyarakat masih enggan beralih ke bank syariah.

Indonesia dan Malaysia merupakan dua Negara di kawasan Asia Tenggara yang merupakan penggerak berkembangnya industri perbankan syariah. Dengan berkembangnya sistem perbankan dan keuangan syariah di dua negara tersebut mendorong negara-negara di kawasan Asia Tenggara untuk berpartisipasi dalam mengembangkan industry keuangan syariah. Mengingat pada tahun 2015 telah terjadi integrasi ekonomi Negara-negara ASEAN di mana sektor keuangan syariah termasuk di dalamnya (Rama, 2015).

Selain di kedua negara ASEAN tersebut, perbankan syariah juga berkembang di Brunei Darussalam. Negara ini termasuk negara berpenduduk muslim yang cukup intens mengembangkan industri keuangan syariah. Singapura sebagai negara minoritas Muslim yang bertetangga dengan Malaysia dan Indonesia juga punya ambisi untuk mengembangkan industri keuangan syariah. Bahkan negara tersebut sudah memproklamirkan diri untuk menjadi pusat keuangan syariah di kawasan Asia bahkan di dunia. Ambisi ini tentunya didukung oleh reputasi negara Singapura sebagai pusat keuangan di dunia selama ini (Rama, 2015).

Indonesia seharusnya menjadi pasar yang sangat potensial bagi perbankan syariah. Hal ini disebabkan Indonesia memiliki penduduk muslim terbesar di dunia. Berdasarkan data Badan Pusat Statistik 
Indonesia pada tahun 2010 mengenai jumlah penduduk Indonesia menurut agama yang dianut, pemeluk agama islam sebesar 207.176.162 jiwa dari total 237.641.326 jiwa atau sebesar 87, $18 \%$. Dengan penduduk mayoritas muslim dapat menjadi potensi atau peluang terhadap industri perbankan syariah. Tetapi kesadaran konsumen terhadap industri syariah di Indonesia masih sangat minim, hal ini dapat dilihat melalui pangsa pasar yang di peroleh bank syariah saat ini masih 5, 3\%.

Bagaimana menumbuhkan niat masyarakat untuk beralih (swithing) dari bank konvensional ke bank syariah merupakan hal sangat penting untuk meningkatkan pangsa pasar perbankan syariah di Indonesia. Industri perbankan yang kompetitif berfokus pada perilaku perpindahan nasabah (customer switching behavior) dan perpindahan penyedia jasa tersebut dapat mengurangi pangsa pasar dan keuntungan dari bank (Clemes D. et.al, 2010).

Switching intention (intensi berpindah) merupakan tingkat kemungkinan atau kepastian bahwa pelanggan akan berpindah dari penyedia jasa saat ini kepada penyedia jasa baru (Bansal dalam Hizbul, 2017, p. 25). Salah satu penyebab utama pelanggan berpindah penyedia layanan (provider) adalah pelayanan yang buruk. Perpindahan pelanggan memberikan efek bagi perusahaan diantaranya penurunan pangsa pasar, berkurangnya pendapatan, dan peningkatan word of mouth yang negatif (Khan et al., 2014).

Pengaruh dari kualitas pelayanan, persepsi konsumen, behavioral intention, dan perceived value adalah faktor yang siknifikan terhadap kepuasan pelanggan dimana merupakan prediktor yang signifikan dari switching intention, dan kepuasan pelanggan merupakan asset tidak berwujud yang sangat penting bagi perusahaan untuk meraih keuntungan (Peng, lai, Chen, \& wel, 2015; Ryuu, Lee, \& Gon Kim, 2012 dalam Jamil dan Akhter, 2016).

Persepsi memiliki pengaruh yang signifikan dengan menggunakan kepuasan pelanggan sebagai mediator terhadap customer switching intention (Jamil dan Akhter, 2016). Dengan demikian dapat di tarik asumsi bahwa perpindahan nasabak bank konvensional dipengaruhi adanya persepsi dan juga kepuasan pelanggan terhadap bank syariah.

Hawkins dan Mothersbaugh (2016), menyatakan bahwa persepsi adalah sebuah proses yang dimulai dengan adanya paparan (exposure), dan perhatian (attention) dari konsumen atas rangsangan pemasaran (marketing stimuli) yang di akhiri dengan interpretasi konsumen (interpretation) (p. 274). Menurut Koter dan Keller (2016) mendefinisikan kepuasan sebagai perasaan senang atau kecewa seseorang yang timbul setelah membandingkan kinerja yang telah dipersepsikan suatu produk atau jasa dengan harapannya. Jika kinerja gagal memenuhi harapannya, maka pelanggan akan merasa tidak puas. Jika kinerja sesuai dengan harapannya, maka pelanggan akan merasa puas. Jika melebihi harapannya, maka pelanggan akan merasa sangat puas atau senang (p. 153).

Bagi perusahaan yang bergerak di bidang jasa perbankan, memberikan kepuasan kepada nasabahnya adalah hal pokok yang tidak boleh diabaikan, dimana kepuasaan nasabah merupakan aspek stategis dalam memenangkan persaingan dan mempertahankan citra perusahaan di masyarakat yang luas, sehingga pelayanan yang bermutu bagi nasabah merupakan hal penting. Dengan adanya perbankan syariah yang telah memasuki persaingan berskala global, merupakan suatu tantangan yang harus dihadapi dan ditangani oleh bank syari'ah untuk dapat memberikan kontribusi dalam pembangunan bangsa melalui pemberdayaan ekonomi umat. Dalam teori perilaku konsumen, kepercayaan masyarakat dapat diperoleh dari sebuah perusahaan dengan menggunakan beberapa cara, di antaranya adalah dengan memberikan rangsangan pemasaran dari dalam dan luar perusahaan. Rangsangan pemasaran dari dalam perusahaan dapat berbentuk seperti iklan, promosi, dan sebagainya yang menerangkan tentang kualitas produk (barang maupun jasa), harga dan saluran distribusinya. Sedangkan rangsangan dari luar dapat berupa kondisi ekonomi, politik, teknologi dan kebudayaan 
yang ada di masyarakat setempat (https://adisujai.wordpress.com/2010/08/15/kualitas-pelayanandan-kaitannya-dengan-kepuasan-nasabah-bank-syariah/).

\section{Kajian Literatur \\ Persepsi}

"Perception is a process that begins with consumer exposure and attention to marketing stimuli and ends with consumer interpretation." (Hawkins dan Motherbaugh, 2016, p. 274) artinya bahwa persepsi adalah sebuah proses yang dimulai dengan adanya paparan (exposure), dan perhatian (attention) dari konsumen atas rangsangan pemasaran (marketing stimuli) yang di akhiri dengan interpretasi konsumen (interpretation).

a. Exposure merupakan paparan informasi yang diterima oleh otak kita dan tidak mendapatkan perhatian yang besar. Exposure ini biasanya mendapatkan sebagai stimulus yang diterima oleh seseorang karena biasanya seseorang akan lebih memberikan perhatian dan mendapatkan stimulus lebih ketika seseorang mengangap bahwa informasi yang dibutuhkan itu ada. Namun dalam Exposure ini bisa disebutkan bahwa seseorang menganggap bahwa paparan merupakan informasi yang tidak akan membantu dalam mendapatkan tujuannya.

b. Attention adalah perhatian seseorang terhadap suatu objek yang dianggap dapat membantu untuk mencapai tujuan yang dimiliki seseorang berdasarkan informasi yang menarik perhatian orang tersebut. Attention ini terdiri dari karakteristik stimulus, individual dan situasional.

c. Interpretation adalah penginterpretasian sebuah informasi untuk dipahami yang masuk kedalam otak seseorang berdasarkan stimulus yang diterima dari indera yang dimiliki oleh seseorang.

d. Memory adalah informasi yang berada di otak seseorang baik informasi yang memiliki jangka panjang atau pendek. Biasanya informasi yang berasal dari tahap exposure atau paparan akan memiliki memori jangka pendek, sedangkan informasi yang didapatkan atas attention atau perhatian seseorang akan cenderung tersimpan lebih lama dan memiliki jangka panjang didalam memori seseorang.

e. Perception merupakan persepsi yang terbentuk atas paparan, perhatian dan interpretasi seseorang terhadap objek dengan mendapatkan sebuah informasi yang tersimpan di memori atau otak seseorang baik jangka panjang maupun jangka pendek. Dari teori-teori yang sudah dijelaskan, persepsi itu merupakan kegiatan yang dilakukan oleh seseorang dalam memberikan makna terhadap rangsangan. Persepsi ini diawali dengan stimulus seseorang terhadap sebuah objek. Stimulus yang diaktifkan akan menghasilkan sensasi yang dihasilkan dan diproses melalui otak tersebut.

\section{Customer Satisfaction}

Kepuasan adalah perasaan senang atau kecewa seseorang yang timbul setelah membandingkan kinerja yang telah dipersepsikan suatu produk atau jasa (atau hasil) dengan harapannya (Kotler dan Keller, 2016, p. 153). Jika kinerja gagal memenuhi harapannya, maka pelanggan akan merasa tidak puas. Jika kinerja sesuai dengan harapannya, maka pelanggan akan merasa puas. Jika melebihi harapannya, maka pelanggan akan merasa sangat puas atau senang.

Kepuasan konsumen adalah suatu tingkatan dimana kebutuhan, keinginan dan harapan pelanggan dapat terpenuhi yang akan mengakibatkan terjadinya bembelian ulang atau kesetiaan yang berlanjut (Band dalam Nelloh dan Liem, 2011).

\section{Customer Switching Intention}

Switching intention (intensi berpindah) merupkan tingkat kemungkinan atau kepastian bahwa pelanggan akan berpindah dari penyedia jasa saat ini kepada penyedia jasa baru (Banzal dalam Hizbul, 2017, p. 25).

Banyak studi perpindahan pelanggan menjelaskan bahwa faktor-faktor penentu perpindahan, seperti kualitas, kepuasan, biaya berpindah, dan ketertarikan atas alternatif, telah dimodelkan dengan intensi 
berpindah.Beberapa faktor yang mempengaruhi perpindahan pelanggan dikelompokkan ke dalam tiga kategori, yaitu efek pendorong (push effects), efek penarik (pull effects), dan efek penambat (mooring effects)(Bansal, et.al., 2005).

Terdapat tiga jenis intensi (Haryanto dan Chairy dalam Hizbul, 2017, p. 25) yaitu:

a. Intensi sebagai harapan, yaitu harapan-harapan yang timbul dalam diri seseorang untuk melakukan sesuatu.

b. Intensi sebagai keinginan, yaitu keinginan dalam diri seseorang untuk melakukan sesuatu.

c. Intensi sebagai rencana, yaitu rencana seseorang untuk melakukan sesuatu.

\section{Hubungan Persepsi dengan Customer Satisfaction}

Persepsi adalah hasil interpretasi konsumen dari paparan mengenai informasi atau stimuli. Menurut Kotler dan Keller dalam Gusasi (2014) kepuasan pelanggan dipengaruhi oleh fitur khusus produk atau jasa yaitu persepsi kualitas produk, pelayanan dan harga. Persepsi merupakan salah satu faktor yang dapat mempengaruhi kepuasan pelanggan (Jamil dan Akhter, 2016). Jamil dan Akhter juga mengungkapkan bahwa shari'ah perceptionjuga memiliki pengaruh yang positif terhadap customer satisfaction. Konsumen akan merasa puas apabila harapan, keinginan, dan kebutuhan mereka terpenuhi. Kenaikan persepsi nilai dan kepercayaan akan meningkatkan kepuasan konsumen (Iqbal, 2008).

\section{Hubungan Customer Satisfaction dengan Customer Switcing Intention}

Switching intention sebagai tingkat kemungkinan atau kepastian bahwa pelanggan akan berpindah dari penyedia jasa saat ini kepada penyedia jasa yang baru (Bansal, et.al, 2005). Banyak studi perpindahan pelanggan menjelaskan bahwa faktor-faktor penentu perpindahan, seperti kualitas, kepuasan, biaya berpindah, dan ketertarikan atas alternatif, telah dimodelkan dengan intensi berpindah. Pernyataan tersebut sejalan dengan penelitianyang dilakukan oleh Gusasi (2014) bahwa meningkatkan kualitas layanan untuk meningkatkan kepuasan pelanggan akan menurunkan switching intention. Sustomer satisfaction, high price, dan company nameintention memiliki hubungan yang positif terhadap customer switching intention (Khan, et.al, 2014).

\section{Hubungan Persepsi dengan Customer Satisfaction dan Customer Switcing Intention}

Jamil dan Akhter (2016) menyatakan bahwa persepsi dapat mempengaruhi customer switcing intention secara tidak langsung. Persespi yang dimediasi oleh customer satisfaction dapat mempengaruhi customer switcing intention. Gusasi (2014) mrnggunakan kepuasan pelanggansebagai variabel mediasi dalam penelitian nya mengenai pengaruh kualitas layanan terhadap switching intention. Selain itu penelitian yang dilakukan oleh Nelloh dan Liem (2011) juga menggunakankepuasan pelanggan untuk memediasi kualitas layanan dan switching intention. Penelitian lain dilakukan oleh Wijaya dan Herdioko (2010) menyebutkan bahwa kualitas, persepsi nilai citra dan kepuasan memiliki pengaruh terhadap loyalitas atau keinginan berpindah konsumen, dimana kualitas memiliki pengaruh yang signifikan, sementara citra dan persepsi nilai tidak memiliki pengaruh signifikan kepada kepuasan konsumen dan kepuasan tidak memiliki hubungan terhadap loyalitas dan switching intention.

\section{Kerangka Berfikir}

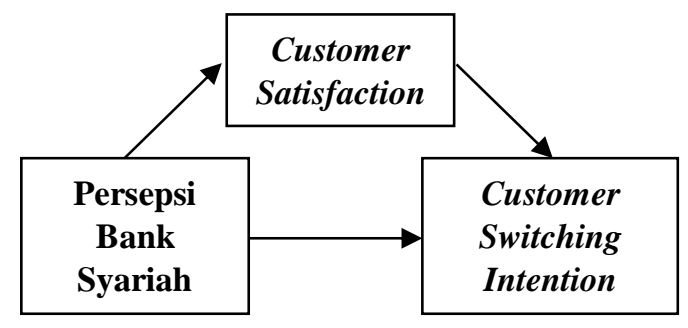

Gambar 1

Kerangka Berfikir 
Metode Penelitian

Jenis Penelitian, Populasi dan Sampel

Jenis penelitian yang dilakukan oleh peneliti adalah penelitian kuantitatif dengan metode survey untuk menguji hubungan antar variabel dan membuat prediksi berdasarkan korelasi (korelasional). Populasi dalam penelitian ini adalah seluruh pengguna atau nasabah dari bank konvensional seluruh Indonesia yang jumlahnya tidak diketahui secara pasti.

Sampel yang digunakan dalam penelitian ini adalah nasabah bank konvensional yang berada di Kota Bandung sebanyak 100 berdasarkan perhitungan rumus Bernauli.

\section{Teknik Analisis Data}

Analisis Deskriptif

Untuk mengetahui bagaimana tanggapan responden mengenai masing-masing variabel, maka digunakan garis kontinum. Garis kontinum digunakan sebagai alat untuk mengolah data sehingga dapat di analisis secara deskriptif.

\section{Analisis Path Dengan Menggunakan Permodelan SEM (Structural Equation Modelling)}

Structural Equation Model (SEM) adalah suatu teknik statistika untuk menguji dan mengestimasi hubungan kausal dengan mengintegrasi analisis faktor dan analisis jalur. SEM adalah pengembangan dari General Linear Model (GLM) dengan regresi berganda sebagai bagian utamanya. Namun SEM lebih andal, ilustratif, dan kokoh dibantingkan teknik regresi ketika memodelkan interaksi, nonlinearitas, error pengukuran, korelasi error terms dan korelasi antar variabel laten yang diukur oleh indicator berganda. SEM juga dapat digunakan sebagi alternatif analisis jalur dan analisis data runtun waktu yang berbasis kovarian (Abdillah dan Hartono, 2015, p. 140-141).

\section{Analisis Statistik Inferensial}

Statistik inferensial adalah teknik statistic yang digunakan untuk menganalisis data sampel dan hasilnya diberlakukan untuk populasi (Sugiyono, 2012). Sesuai dengan hipotesis yang dirumuskan, maka dalam penelitian ini analisis data statistik inferensial diukur dengan menggunakan software SmartPLS 3 mulai dari pengukuran model (outer model), struktur model (inner model), dan pengujian hipotesis.

\section{Hasil dan Diskusi \\ Hasil \\ Karakteristik Responden}

Jumlah responden perempuan sebanyak 53 orang dan responden laki-laki sebanyak 47 orang. Usia responden 31-40 tahun yaitu sebesar 41\%, usia responden 23-30 tahun yaitu sebesar 32\%, usia responden $\geq 40$ tahun yaitu sebesar $19 \%$, dan usia responden 17-22 tahun sebesar $8 \%$. Jumlah responden berdasarkan pendidikan S1/Sarjana sebesar 46\%, SMA/Sederajat dan Diploma /Sarjana muda dengan masing-masing adalah 25\%, dan Pasca Sarjana 4\%. Pekerjaan responden sebagai Pegawai Swasta sebesar 26\%, Wiraswasta sebesar 23\%, Pegawai Negeri sebesar 23\%, BUMN sebesar 19\%, dan Pelajar/Mahasiswa sebesar 9\%. Responden berdasarkan rata-rata pendapatan perbulan Rp 3.000.001-Rp 5.000.000 sebanyak 38\%, rentang Rp 1.000.001-Rp 3.000.000 sebanyak $32 \%$, $\geq \mathrm{Rp} 5.000 .001$ sebanyak 25\%, $\leq \mathrm{Rp} 1.000 .000$ sebanyak 5\%. Bank konvensional yang digunakan responden adalah Bank BRI yaitu sebesar 29,84\%, Bank BNI sebesar 27,42\%, Bank Mandiri yaitu sebesar 22,58\%, Bank BCA yaitu sebesar 20,16\%.

\section{Predictive Relevance}

$R$-square model PLS dapat dievaluasi dengan melihat $Q$-square predictive relevance untuk model variabel. $Q$-square mengukur seberapa baik nilai observasi yang dihasilkan oleh model dan juga estimasi parameternya (uji goodness-fit model). 


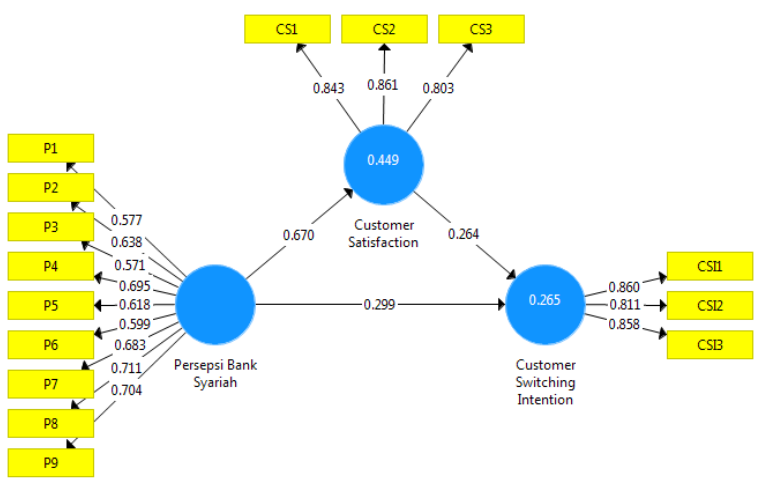

Gambar 2

Hasil PLS Alogarithm, R-Square

$$
\begin{gathered}
Q^{2}=1\left(1-R_{1}{ }^{2}\right)\left(1-R_{2}{ }^{2}\right) \ldots \ldots\left(1-R_{p}{ }^{2}\right) \\
Q^{2}=1\left(1-0,449^{2}\right)\left(1-0,265^{2}\right) \\
Q^{2}=1(0,798)(0,929) \\
Q^{2}=0,741
\end{gathered}
$$

Berdasarkan hasil perhitungan diatas dapat diketahui bahwa model konstruk memiliki nilai $Q$-square sebesar $0,741(0,741>0)$ sehingga dapat dikatakan bahwa model konstruk memiliki prediktif yang relevan.

\section{Inner Model}

Model struktural (inner model) merupakan model struktural menunjukkan spesifikasi hubungan kausal antar variabel laten ${ }^{18}$. Melalui proses bootstrapping, parameter uji $T$-statistic diperoleh untuk memprediksi adanya hubungan kausalitas. Proses bootstapping dilakukan untuk mengetahui hasil Tstatistic sehingga dapat dilakukan pengujian hipotesis dengan criteria sebagai berikut:

1. Jika t-tabel $>\mathrm{t}$-statistik, $\mathrm{H} 0$ diterima, $\mathrm{H} 1$ ditolak

2. Jika t-tabel < t-statistik, H0 ditolak, H1 diterima

Hasil pengujian dari penyebaran kuesioner pada penelitian melalui proses bootstapping pada program SmartPLS 3.0adalah sebagai berikut:

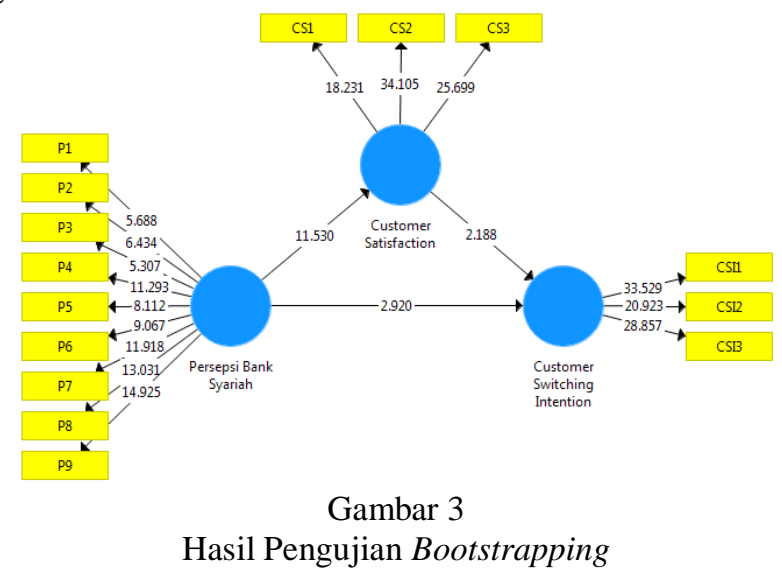

Hasil pengujian masing-masing hipotesis adalah sebagai berikut:

1. Persepsi Bank Syariah terhadap Customer Satisfaction

Nilai T-statistic $(11,530)>$ T-tabel 1, 96 sehingga H1 diterima H0 ditolak. Artinya variabel Persepsi Bank Syariah berpengaruh terhadap Customer Satisfaction dengan signifikansi 5\%. Besar koefisien pengaruh Persepsi Bank Syariah terhadap Customer Satisfaction sebesar 0,670.

2. Customer Satisfaction terhadap Customer Switching Intention

Nilai T-statistic $(2,188)>$ T-tabel 1, 96 sehingga H1 diterima H0 ditolak. Artinya variabel Customer Satisfaction berpengaruh terhadap Customer Switching Intention dengan signifikansi 
5\%. Besar koefisien pengaruh Customer Satisfaction terhadap Customer Switching Intention sebesar 0,264.

3. Persepsi Bank Syariah terhadap Customer Switching Intention

Nilai T-statistic $(2,920)>$ T-tabel 1, 96 sehingga H1 diterima H0 ditolak. Artinya variabel Persepsi Bank Syariah berpengaruh terhadap Customer Switching Intention secara langsung dengan signifikansi 5\%. Besar koefisien pengaruh langsung Persepsi Bank Syariah terhadap Customer Satisfaction sebesar 0, 299.

4. Persepsi Bank Syariah dengan dimediasi Customer Satisfaction terhadap Customer Switching Intention.

Nilai T-statistic $(2,056)>$ T-tabel 1, 96 sehingga H1 diterima H0 ditolak. Artinya variabel Persepsi Bank Syariah dengan dimediasi Customer Satisfaction berpengaruh terhadap Customer Switching Intention dengan signifikansi 5\%. Besar koefisien pengaruh Persepsi Bank Syariah terhadap Customer Satisfaction sebesar 0,177.

\section{Diskusi}

Berdasarkan hasil pengujian boostrapping untuk menguji pengaruh persepsi bank syariah terhadap customer satisfaction menunjukkan bahwa persepsi bank syariah berpengaruh secara positif terhadap customer satisfaction dengan besar koefisien hubungan sebesar 0,670. Hal ini menunjukkan bahwa bank syariah memiliki persepsi positif yang membuat responden merasa puas. Sejalan dengan penelitian yang dilakukan oleh Iqbal (2008) yang menyatakan bahwa persepsi nilai mempengaruhi kepuasan konsumen secara positif dan signifikan. Selain itu penelitian yang dilakukan oleh Jamil dan Akhter (2016) juga mengungkapkan bahwa shari'ah perception memiliki pengaruh yang positif terhadap customer satisfaction. Sehingga dapat disimpulkan bahwa persepsi yang positif dapat mempengaruhi customer satisfaction secara positif.

Berdasarkan hasil pengujian boostrapping untuk menguji pengaruh customer satisfaction terhadap customer switching intention menunjukkan bahwa customer satisfaction berpengaruh secara positif terhadap customer switching intention dengan hubungan koefisien hubungan sebesar 0,264. Hal ini menunjukkan bahwa responden yang merupakan nasabah bank konventional merasa puas terhadap informasi yang diperoleh mengenai bank syariah sehingga responden memiliki niat untuk berpindah penyedia jasa perbankan. Penelitian yang dilakukan oleh Gusasi (2014) menyebutkan bahwa kepuasan pelanggan berpengaruh secara signifikan terhadap switching intention. Sedangkan Penelitian yang dilakukan oleh Khan et al., 2014 mengatakan bahwa customer satisfaction, high price, dan company nameintention memiliki hubungan yang positif terhadap customer switching intention.

Berdasarkan hasil pengujian boostrapping untuk menguji pengaruh persepsi bank syariah terhadap customer switching intention menunjukkan bahwa persepsi bank syariah berpengaruh secara positif terhadap customer switching intention dengan hubungan koefisien hubungan sebesar 0,299. Hal ini menunjukkan bahwa persepsi bank syariah dapat mempengaruhi nasabah bank konventional untuk berpindah (switching) ke bank syariah secara langsung. Hal ini sesuai dengan penelitian yang dilakukan oleh Jamil dan Akhter (2016) bahwa persepsi memiliki pengaruh langsung yang lebih besar terhadap customer switching intention dibandingkan dengan pengaruh yang dimediasi oleh customer satisfaction, dalam penelitian ini persepsi memiliki pengaruh negatif terhadap customer switching intention.

Berdasarkan hasil pengujian boostrapping untuk menguji pengaruh persepsi bank syariah dengan dimediasi oleh customer satisfaction terhadap customer switching intention menunjukkan bahwa persepsi bank syariah berpengaruh secara positif tidak langsung terhadap customer switching intention dengan hubungan koefisien hubungan sebesar 0,177 . Hal ini menunjukkan bahwa pengaruh tidak langsung persepsi bank syariah dengan dimediasi oleh customer satisfaction lebih kecil dibandingkan dengan pengaruh persepsi bank syariah terhadap customer switching intention secara langsung. Hasil temuan ini sesuai dengan penelitian yang dilakukan oleh Jamil dan Akhter (2016) 
bahwa persepsi memiliki pengaruh langsung yang lebih besar terhadap customer switching intention dibandingkan dengan pengaruh yang dimediasi oleh customer satisfaction. Perbedaan dengan penelitian yang dilakukan oleh Jamil dan Akhter (2016) adalah bahwa persepsi memiliki pengaruh negatif terhadap customer switching intention, sedangkan dalam penelitian ini persepsi bank syariah memiliki pengaruh yang negatif customer switching intention.

\section{Simpulan}

Simpulan dalam penelitian ini adalah sebagai berikut:

1. Pengaruh persepsi bank syariah terhadap customer satisfaction Bank Syariah di Indonesia. Berdasarkan hasil pengujian boostrapping untuk menguji pengaruh persepsi bank syariah terhadap customer satisfaction menunjukkan bahwa persepsi bank syariah berpengaruh secara positif terhadap customer satisfaction dengan besar koefisien hubungan sebesar 0,670. Hal ini menunjukkan bahwa bank syariah memiliki persepsi positif yang membuat responden merasa puas.

2. Pengaruh customer stisfaction terhadap customer switching intention Bank Syariah di Indonesia. Berdasarkan hasil pengujian boostrapping untuk menguji pengaruh customer satisfaction terhadap customer switching intention menunjukkan bahwa customer satisfaction berpengaruh secara positif terhadap customer switching intention dengan hubungan koefisien hubungan sebesar 0,264. Hal ini menunjukkan bahwa responden yang merupakan nasabah bank konventional merasa puas terhadap informasi yang diperoleh mengenai bank syariah sehingga responden memiliki niat untuk berpindah penyedia jasa perbankan.

3. Pengaruh persepsi bank syariahterhadap customer switching intention Bank Syariah di Indonesia. Berdasarkan hasil pengujian boostrapping untuk menguji pengaruh persepsi bank syariah terhadap customer switching intention menunjukkan bahwa persepsi bank syariah berpengaruh secara positif terhadap customer switching intention dengan hubungan koefisien hubungan sebesar 0,299. Hal ini menunjukkan bahwa persepsi bank syariah dapat mempengaruhi nasabah bank konvensional untuk berpindah (switching) ke bank syariah secara langsung.

4. Pengaruh persepsi bank syariah dengan dimediasi oleh customer satisfaction terhadap customer switching intention Bank Syariah di Indonesia.

Berdasarkan hasil pengujian boostrapping untuk menguji pengaruh persepsi bank syariah dengan dimediasi oleh customer satisfaction terhadap customer switching intention menunjukkan bahwa persepsi bank syariah berpengaruh secara positif tidak langsung terhadap customer switching intention dengan hubungan koefisien hubungan sebesar 0,177. Hal ini menunjukkan bahwa pengaruh tidak langsung persepsi bank syariah dengan dimediasi oleh customer satisfaction lebih kecil dibandingkan dengan pengaruh persepsi bank syariah terhadap customer switching intention secara langsung.

\section{Daftar Pustaka}

Abdillah, W. dan Hartono, J. (2015). Partial Least Aquare (PLS) Alternatif Structural Equation Modeling (SEM) dalam Penelitian Bisnis. Yogyakarta: Andi.

Bansal, Harvir, S., Shirley, F., Taylor, \& Yannik St. (2005). Migrating to New Service Providers : Toward a Unifying Framework of Customers Switching Behaviors". Journal of The Academy of Marketing Science, Vol. 33, No.1.

Clemes, D. M, et.al. (2010). Customer Switching Behavior in Chinese Retail Banking Industry. International Jurnal of Bank Marketing Vol.28 No.7 2010 pp.519-540.

Gusasi, N. Y. (2014). Pengaruh Kualitas Layanan Terhadap Kepuasan Pelanggan dan Dampaknya Terhadap Switching Intention Pengguna Jasa Rumah Kos di Kawasan Telkom University. Bandung: Universitas Telkom. 
Hawskins, D. I. \&Mothersbaugh, David L. (2016). Consumer Behaviour Building: Marketing Strategy (Thirteenth Edition). New York NY: The McGraw-Hill.

Hizbul, A. (2017). Pengaruh Kualitas Layanan dan Persepsi Harga Terhadap Kepuasan Nasabah dan Switcing Intention. Universitas Muhammadiyah Yogyakarta.

Iqbal, M. (2008). Pengaruh Persepsi Nilai, Harapan, dan Kepercayaan Terhadap Kepuasan Konsumen pada Penyedia Jasa Internet di Jabodetabek. Universitas Gunadarma.

Jamil, H. dan Akhter, W. (2016). Investigating the Impact of Shari'ah Perception on Customer Switching Intention: A Study of Takaful and Conventional Insurance. Jamil \& Akhter, Cogent Business \& Manajement (2016), 3:1261525.

Khan, M. A., et.al. (2014). Attitude of People Towards Retention and Switching: A Study Based on Nestle in Pakistan. ISSN 2161-7104, 2014, Vol 4 No 2.

Kotler, P. and Keller, K. L. (2016). Marketing Management $15^{\text {th }}$ Edition. New Jersey: Person Prentice Hall, Inc.

Nelloh, L.A.M dan Liem, C.C.P. (2011). Analisis Switching Intention Pengguna Jasa Layanan Rumah Kos di Siwalankerto: Perspektif Kualitas Layanan dan Kepuasan Pelanggan. Jurnal Manajemen Pemasaran, Vol 6, No. 1.

Rama, Ali. (2015). Analisis Deskriptif Perkembangan Perbankan Syariah Di Asia Tenggara. The Journal of Tauhidinomics Vol.1 No.2 (2015): 105-128.

Sugiyono. (2012). Metode Penelitian Kuantitatif, Kualitatif dan R\&D. Bandung: Alfabeta.

Tjiptono, F. (2014). Pemasaran Jasa, Prinsip, Penerapan dan Peneltian. Yogyakarta: Penerbit ANDI.

Wijaya, P. S. M. dan Herdioko, J. (2010). Pengaruh Kualitas, Persepsi Nilai, Citra, Dan Kepuasan Terhadap Loyalitas atau Keinginan Berpindah Penumpang Bus Transjogja. JRMB, Volume 5, No. 2, Desember 2010.

http://www.tribunnews.com/bisnis/2016/07/01/tiga-persepsi-yang-selama-ini-salah-tentang-banksyariah. Tiga Persepsi Yang Selama Ini Salah Tentang Bank Syariah. Diakses pada tanggal 23 September 2017.

http://www.gomuslim.co.id/read/opini/2017/04/08/3732/bank-halal-itu-bernama-bank-syariah.html. Bank Halal Itu Bernama Bank Syariah. Diakses pada tanggal 23 September 2017.

https://adisujai.wordpress.com/2010/08/15/kualitas-pelayanan-dan-kaitannya-dengan-kepuasannasabah-bank-syariah/. Kualitas Pelayanan Dan Kaitannya Dengan Kepuasan Nasabah Bank Syariah. Diakses pada tanggal 29 November 2017. 